\title{
Mengkaji Ulang Makna Hadits "Surga di bawah Telapak Kaki Ibu" dalam Perspektif Islam
}

\section{Reassessing the Meaning Of Hadist "Heaven is Under Mother's Feet", in Islamic Perspective}

\author{
Romlah $^{1 \cdot}$
}

IJurusan Tarbiyah Fakultas Agama Islam Universitas Muhammadiyah Malang, Jln. Raya Tlogomas no. 246, Malang 65144; Email : romlah@umm.ac.id

Abstrak. Pemberian makna hadits ini dilatarbelakangi oleh realitas akan keberadaan kaum perempuan secara jeneral pada saat sebelum datangnya Islam hingga sekarang sangat tidak berpihak kepada perempuan, meski sebagian besar mereka telah melakukan berbagai perubahan, demi menggapai kesempurnaan sebagai insan kamil (manusia sempurna). Diantaranya dengan menambah ilmu pengetahuan, baik melalui pendidikan formal (sekolah dari jenjang TK - PT), non formal (mengikuti kursus, pelatihan dan lain-lain sesuai dengan bakat dan minatnya atau tuntutan kerja) dan in formal (pengasuhan, pemberian pemahaman dan pengarahan oleh orang tua di rumah). Selanjutnya, mereka memasuki dunia kerja, baik pada sektor publik maupun pada sektor domestik. Dengan demikian, peran dan tanggung jawabnya semakin bertambah. Dengan bertambahnya kesibukan masing-masing ibu pada persoalan kehidupan dunia, seharusnya diimbangangi dengan kemampuan keislaman yang kuat, sehingga dalam pelaksanaannya tidak mudah terombang-ambing oleh arus globalisasi yang semakin tidak humanis. Bertolak pada kenyataan ini, maka tulisan ini mengajak kepada para pembaca yang budiman meluangkan waktu sejenak untuk intropeksi diri sebagai seorang ibu yang melahirkan generasi penerus dalam menghadapi percaturan arus yang penuh daya tipuan, hedonis, materialistis, dan lain-lain. Oleh karena itu, ibu sebagai seorang muslimah hendak memahami sabda Nabi Muhammad SAW: "Aljannatu tahta aqdami al-ummati, artinya Surga di bawah telapak kaki kaum ibu".'Hadits ini sangat penting sekali untuk dikaji ulang secara bersama-sama, apakah diantara kita sebagai ibu berhak merebutkan piala surga yang dijanjikan Allah untuk hamba-Nya. Untuk itu menurut hemat kami, surga itu dapat kita peroleh manakala adanya niat, ikhlas, penciptaan lingkungan yang Islami, masing-masing ibu-bapak mampu memainkan peran dalam keluarga, dan berdoa kepada Allah jangan sampai ditinggalkan.

Kata kunci : Hadits " Aljannatu tahta aqdami al-ummati", ibu

Abstract. Giving the meaning of this hadith is motivated by the reality of the existence of women as general at the time before the advent of Islam until now is very unfavorable to women, although most of them have made various changes, in order to reach perfection as a perfect human. For example by increase knowledge, either through formal education (schools from kindergarten - university level), non-formal (follow courses, training and others according to their talents and interests or demands of work) and in formal (parenting, given understanding and guidance by parents at home). Furthermore, they enter the workforce, both in the public sector and the domestic sector. Thus, their role and responsibilities are increase. By increasing the busyness of each mother in the life's problem, it should balance with strong Islamic capability, so the implementation is not easily swayed by globalization which is increasingly inhumane. Contrary to this fact, then this article invite the readers to take a moment to self introspect as a mother who gave birth to the next generation in facing flow constellation with full of hoax, hedonistic, materialistic, etc. Therefore, as a Muslim, mother should understand the words of the Prophet Muhammad: "Aljannatu tahta aqdami al-ummati, the meaning is Heaven is under mother's feet." This hadith is very important to be reassessed together, whether among us as mothers are deserve to grab heaven which promised by God to His mankind. Hence, we consider heaven can be obtained when there is 
Jurnal Perempuan dan Anak, 1(1):

Januari 2015

ISSN 2442-2614

Hal. 1 - 13

intention, sincere, the creation of an Islamic environment, each mother-father is able to play a role in the family, and pray to God not to be abandoned.

Key Words: Hadith "Aljannatu tahta aqdami al-ummat", mother

\section{Pendahuluan.}

Membicarakan tentang perempuan (termasuk sosok ibu), tidak akan habis-habisnya, apalagi pembicaraan itu dikaitkan dengan keindahan dan kemolekan tubuhnya. Padahal keindahan seseorang termasuk keindahan perempuan dapat dikelompokkan menjadi 2, yaitu keindahan lahir dan keindahan batin'. Dua unsur keindahan perempuan ini telah diabadikan oleh Rasulullah melalui sabdanya: "Inna Ilaha jamülun yuhibbu al-jamaala" = Artinya: "Sesungguhnya Allah itu indah dan mencintai keindahan". Hadits ini diperkuat dengan hadits lain yang artinya "Sesungguhnya Allah tidak melihat rupa dan postur tubuh kalian, akan tetapi Allah melihat pada hati kalian"s.

Dua hadits ini nampak sekali lebih mengedepankan keindahan batin (inner beauty), mengingat keindahan batin itulah yang dicari esensi dari keindahan seseorang (termasuk perempuan). Seperti keindahan ilmu, akal fikiran dan kesucian diri. Keindahan batin merupakan titik pandang Allah dari hamba-hamba-Nya, mengingat keindahan batin akan terlihat indah, muliah, dan penuh kharisma. Semua itu bisa dimiliki seseorang (termasuk seorang perempuan), tergantung sejauhmana sifat-sifat itu tertanam dalam batinnya.

${ }^{1}$ Khalid Jamal, 2008, Inner Beauty: Tips Cantik Dunia Akhirat, Jakarta: Embun Publishing, hal. 3-5 dan 33-34. Beliau tidak banyak mengupas tentang keindahan lahiyah secara mendetil, meski keindahan itu ada standard dan ukurannya, namun sekilas keindahan lahiriah itu seperti : (1) Keindahan mata, terletak pada warna putih di bola matanya benar-benar putih dan warna hitam yang benar-benar hitam, sehingga warna itu memiliki kelebihan tersendiri. Kecantikan pada mata ini bukan berarti terletak pada keberanian mata untuk menatap sesuatu atau lain jenis, dan bukan juga mata yang jelalatan, baca QS.Waqi'ah ayat 22. (2) Keindahan kulit terletak pada jernih warna kulitnya, hingga seakan-akan memancarkan cahaya (perhatikan wajah kita atau wajah orang lain setelah melakukan wudhu yang hendak melakukan shalat, maka nampak terpancar cahayanya, meski kulitnya hitam atau sawo matang), baca QS. Ar-Rahman ayat 58. (3) Keindahan payudara, terletak pada tersembunyinya, bukan terletak pada terbukanya, baca QS.An-Naba' ayat 33. (4) Keindahan usia terletak pada kedewasaannya, bukan terletak dapa kekanak-kanakannya, baca QS.Waqi'ah ayat 36-37. (5) Keindahan kesucian terletak pada penjagaannya, bukan terletak keperawanannya yang terenggut, baca QS.Shaffat ayat 49. (6) Keindahan cinta terletak pada ketaatan yang sempurna (baca QS.Waqi'ah ayat 37), tidah ambisius terhadap selain yang dicintainya (baca QS.Ash-Shaffat ayat 48), dan tidak ridha kecuali pada kepada suminya (baca QS. Ar-Rahman ayat 72), bukan terletak pada jumlah yang dicintainya. (7) Sinar kecantikan yang sebenarnya terletak antara langit dan bumi ketika matahari terbit (Hadits diriwayatkan olah Bukhari-Muslim yang artinya: "Jika perempuan dari bidadari surga menampakkan diri ke bumi, niscaya baunya akan semerbak dan sinarnya memenuhi langit dan bumi”), bukan pada kecantikan yang dibuat-buat (iimitasi) dan kemanjaan palsu.

${ }^{2}$ Hadits diriwayatkan oleh Muslim dalam Shahinya, hadits no.91, dalam Khalid Jamal, Ibid, hal.3.

${ }^{3}$ Hadits diriwayatkan oleh Muslim dalam Shahinya, hadits no.2564, dalam Khalid Jamal, Ibid, hal.3 dan 38-39. Beliau menguraikan keindahan batin seseorang, termasuk perempuan terletak pada sifat-sifatnya, seperti pertanyaan Ummu Salamah kepada Rasulullah: Ya Rasulullah, manakah yang lebih utama, perempuan dunia atau bidadari yang cantik jelita. Nabi menjawab: perempuan dunia itu lebih utama dari pada mereka (bidadari cantik jelita). Ummu Salamah bertanya lagi, mengapa demikian ?. Nabi menjawab: "Karena shalat, puasa dan ibadah mereka kepada Allah. Allah meletakkan mahkota cahaya di wajah mereka, dan memakaikan kain sutera di tubuhnya. Kulitnya putih bersih, pakaiannya berwarrna hijau, perhiasannya berwarna kekuning-kuningan, sanggulnya mutiara dan sisirnya terdiri dari emas. Mereka berkata: kami hidup abadi dan tidak mati, kami lemah lembut dan tidak jahat sama sekali. Kami selalu mendampingi, dan tidak beranjak sama sekali. Kami ridha, dan tidak pernah marah sama sekali. Berbahagialah orang memiliki kami dan kami memilikinya".Selanjunya Ummi salamah bertanya lagi: ya Rasulullah bagaimana kalau ada perempuan yang menikah lebih dari satu, manakah pria yang menjadi suaminya besok di surga ?. Nabi menjawab: "Perempuan itu disuruh memilih, mana diantara suaminya yang sewaktu di dunia akhlaknya yang terbaik, lalu perempuan (istri) itu berkata: wahai Tuhanku, sesungguhnya lelaki ini (dengan menujuk salah satu suaminya dulu) yang paling baik akhlaknya sewaktu mendampingi aku. Oleh karena itu, nikahkanlah aku dengannya. Nabi bersabda, wahai Ummu Salamah: ahlak yang baik itu akan pergi dengan membawa kebaikan dunia dan akhirat”. 
Begitu juga dengan keindahan lahir, merupakan nikmat Allah yang harus disyukuri. Jika disyukuri dengan bertaqwa dan menjaganya, maka akan semakin menambah keindahannya. Sebaliknya, jika keindahan tubuh itu digunakan untuk mendurhakai-Nya, maka apa yang tampak indah di dunia ini akan berubah menjadi tidak menarik dan menjijikkan, sehingga orang lain akan lari menjauhinya. Dengan kata lain, siapapun perempuan bisa meraih kecantikan sejati (lahir dan batin), manakala ia mampu menjalankan shalat, puasa dan melaksanakan amalan ibadah lainnya ${ }^{4}$.

Terlepas dari keindahan lahir dan batin yang dimiliki oleh perempuan, kaum hawa selalu berbaur dengan kaum adam dalam berbagai aktivitas, sebut saja aktivitas pada sektor domestik hingga pada sektor publik. Berbagai aktivitas tersebut bukan berarti adanya upaya untuk mengeksploitasi dirinya, hingga secara tidak langsung telah merengut kemuliyaan yang dimilikinya. Akan tetapi berkiprahnya dalam berbagai sektor itu tidak lain karena ia memiliki kemampuan, kemauan, skill dan kesempatan untuk melakukannya. Selanjutnya muncul pertanyaan, apakah dengan melakukan berbagai aktivas tersebut kemudian Rasulullah memberikan penghargaan lewat sabdanya "Aljannatu tahta aqdami al-ummati, artinya Surga di bawah telapak kaki kaum ibu”?.

Dalam memberikan jawaban pada hadits ini perlu kiranya untuk dikaji ulang dalam berbagai wacana, baik dari tanggung jawab ibu untuk mendampingi dan mengantarkan putera-puterinya, memberikan pemahaman kepada anggota keluarganya, mendampingi dengan setia suaminya, dan lain-lain. Oleh karena itu, untuk mengkaji ulang perlu dipahami kata kuncinya, yaitu kata surga dan ibu. Ketika dua kata ini dipadukan, maka muncul pertanyaan. Apakah semua ibu masuk surga, atau ibu yang mana bisa masuk surga, atau ibu yang lebih memprioritaskan anak-anak, suami dan keluarga dibandingkan dengan tugas lainnya, atau ibu yang lainnya? Untuk lebih jelasnya, akan diuraikan pada bagian berikut ini.

\section{Pembahasan}

Ketika membicarakan perempuan dengan segala kekurangan dan kelebihan yang dimilikinya bila dikaitkan dengan hadits "Aljannatu tahta aqdami al-ummat", maka ada tiga hal yang akan diuraikan pada bagian ini, yaitu:

\section{A. Potret perempuan sebelum Islam.}

Sejarah menjelaskan bahwa kedudukan perempuan sebelum masuknya Islam di bawah penindasan kaum laki-laki, baik secara sistematis maupun tersektuktur. Hal ini ditandai dan dimulai sejak masa lampau (sebelum masuknya Islam) di berbagai negara belahan dunia dalam berbagai agama yang berbeda. Perempuan telah ditempatkan dalam posisi yang rendah, bahkan nyaris sama dengan hewan maupun benda-benda lain yang dapat diperlakukan semena-mena, sesuai dengan selera hati sang pemilik. Mereka dapat diperjual-belikan kapan saja, dimana saja, dan dengan siapa saja. Seperti pada masa:

1. Peradaban Yunani. Mereka terkenal dengan pemikiran-pemikiran filsafatnya, namun tidak banyak membicarakan hak dan kewajiban perempuan. Dikalangan kaum elit, perempuan ditempatkan (disekap) di istana. Sedangkan kalangan bawah, perempuan nasibnya sangat menyedihkan, karena diperjualbelikan. Bagi perempuan yang berumah tangga, sepenuhnya di bawah kekuasaan suaminya, mereka tidak memiliki hak sipil, apalagi hak waris. Sebagai puncak peradaban Yunani, perempuan diberi kebebasan untuk memenuhi kebutuhan dan selera laki-laki. Seperti melakukan hubungan sex bebas, ini dianggap tidak melanggar kesopanan. Tempat pelacuran digunakan kegiatan politik dan seni. Patung-patung telanjang digunakan sebagai motivasi hidup. Juga para pejabat dan dewa-dewa melakukan hubungan gelap dengan rakyat jelatah, hingga lahirlah "Dewi Cinta”.

2. Peradapan Romawi. Perempuan berada digenggaman ayahnya, setelah ia menikah ada di tangan suami, termasuk juga kewenangan untuk menjual, mengusir, menganiaya dan membunuh. Sedangkan hasil usaha yang telah dilakukan oleh perempuan, menjadi hak milik keluarga laki-laki. Pada zaman Kaisar Constantine terjadinya perubahan perundang-undangan tentang hak kepemilikan terbatas bagi perempuan, dengan catatan setiap melakukan transaksi harus disetujui oleh keluara (suami atau ayah).

${ }^{4}$ Ibid, hal. 40 
3. Peradaban Hindu dan Cina. Hak hidup perempuan yang sudah menikah harus berakhir pada saat kematian suaminya, istri harus dibakar hidup-hidupan bersama mayat suaminya saat di bakar, ini berakhir hingga abad ke-17 Masehi. Disamping itu, perempuan pada masyarakat Hindu sering dijadikan sesajen, yang dipersembahkan pada dewa-dewa.

4. Ajaran Yahudi. Martabat perempuan sama dengan pembantu, ayah berhak menjual anak perempuannya bila tidak memiliki saudara laki-laki. Sedangkan ajarannya menganggap perempuan sebagai sumber laknat, karena itu menyebabkan Adam terusir dari surga.

5. Pandangan pemuka Nasrani. Perempuan adalah senjata iblis untuk menyesatkan manusia. Hasil konsuli pada abad ke-5 Masehi memutuskan bahwa perempuan tidak mempunyai ruh yang suci, sedangkan hasil konsuli abad ke-6 Masehi memutuskan bahwa perempuan diciptakan semata-mata untuk melayani laki-laki, hingga abad pertengan nasib perempuan tetap memprihatinkan. Pada tahun 1805 perundangundangan Inggris mengakui hak suami untuk menjual istri, pada tahun 1882 perempuan Inggris belum memiliki hak pemilikan harta benda secara penuh dan hak menuntut ke pengadilan ${ }^{5}$.

\section{B. Perempuan pada Masa Islam.}

Bertolak pada gambaran yang dialami perempuan pada masa lalu menunjukkan, bahwa penidasan dan ketidakadilan terhadap kaum perempuan sudah dimulai sejak sebelum lahirnya Islam hingga saat ini, baik dilakukan secara tertutup rapi hingga secara terang-terangan. Berbagai alasan dan argumentasi yang mereka kemukakan untuk menutupi atau mendapatkan legitimasi, atau melegalkan terhadap kejahatan yang ia lakukan. Tidak jarang pula ayat-ayat Al-Qur'an maupun Hadits-hadits Nabi dijadikan tameng dan senjata pada penindasan yang ia lakukan. Dengan kata lain, Qur'an dan hadits dijadikan ajaran yang ganas dan tidak bermartabat, yang diselimuti berbagai kepentingan dan alasan.

Selanjutnya muncul pertanyaan, mengapa mereka melakukan seperti itu? Untuk memberikan jawaban kenapa melakukannya, maka jawaban yang paling simpel karena keterbatasan wawasan dan pengetahuannya, ditopang dengan perangkat pembacaan teks yang terbatas, juga tidak ada upaya untuk melakukan diolog dengan orang lain yang memiliki kapasitas pengetahuan yang lebih dibanding dirinya. Sebagai dampak (ini sangat naif) pembacaan teks tersebut, ia mengklim sebagai hasil pembacaan yang sempurna dibanding orang lain. Ironisnya, bila terjadi berbedaan pandangan dengan dirinya, maka pandangan orang lain harus dibuang, dicampakkan, bahkan kalau perlu dimasukkan neraka (dimurtadkan, dibid'ahkan, disyirikkan, dan lain-lain). Pada saat itu, tanpa disadari telah menempatkan dirinya pada posisi Tuhan, sehingga bisa mengfonis seseorang masuk surga atau neraka, mukmin atau kafir, selamat atau celaka, dan lain-lain.

Terlepas dari kekurangan wawasan, pengetahuan dan pembacaan teks, maka kehadiran Islam dengan menghadirkan Qur'an-hadits sebagai pegangan hidup telah mengubah potret perempuan, dari kehidupan yang senduh menjadi terang benderang. Sebut saja tentang:

1. Hak-hak perempuan yang dikupas dalam QS.An-Nisa' ayat 32.

Artinya: "Dan janganlah kamu iri hati terhadap apa yang dikaruniakan Allah kepada sebahagian kamu lebih banyak dari sebahagian yang lain. (karena) bagi orang laki-laki ada bahagian dari pada apa yang mereka usahakan, dan bagi Para wanita (pun) ada bahagian dari apa yang mereka usahakan, dan mohonlah kepada Allah sebagian dari karunia-Nya. Sesungguhnya Allah Maha mengetahui segala sesuatu”.

${ }^{5}$ M.Quraish Shihab, 2003, Wawasan Al-Qur'an: Tafsir Maudhu'I atas Perbagai persoalan Umat, Cetakan XIV, Bandung: PT Mizan Pustaka, hal. 296 - 297. Baca M.Quraish Shihab, 2006, Tafsir Al-Mishbab: Pesan, Kesan dan Keserasian Al-Qur'an, Volume 2, Jakarta: Lentera hati, hal.419-420.

${ }^{6}$ Al-Qur'an dan Terjemahnya, 1427 H, Mujamma' Al Malik Fahd Li Thiba'at Al Mush-haf Asy-Syarif Madinah Al Munawwarah Kerajaan Arab Saudi, hal. 122. 
Ayat ini menjelaskan dan mengajarkan kepada manusia untuk : (a) Meletakkan neraca keadilan bagi lakilaki dan perempuan, masing-masing memperoleh bagian pahala dari Allah sesuai dengan amal perbuatannya (baca QS.Al-Ahzab ayat 35). (b) Hidup yang realistis, antara laki-laki dan perempuan memperoleh anugerah Allah dalam kehidupan di dunia sebagai imbalan usahanya, atau atas dasar hakhaknya (seperti warisan). (c) Setiap orang dibolehkan untuk berandai-andai dan berkeinginan, sepanjang tidak mengantarkan dirinya pada pelanggaran ketentuan Allah. Seperti perempuan yang berangan-angan untuk melakukan pekerjaan yang ditetapkan oleh Allah untuk laki-laki (ikut jihat melawan musuh dengan mengangkat senjata), begitu juga sebaliknya. Karena banyak cara untuk memperoleh pahala, tidak hanya terbatas pada amalan tertentu. (d) Hindari iri hati atau sakit hati terhadap laki-laki yang memperoleh warisan dua kali lipat dari perolehan perempuan. Karena perolehan perempuan tidak hanya bersumber dari harta warisan, tetapi juga dari suaminya yang harus mencukupi kebutuhan hidupnya?

2. Keberadaan perempuan di luar rumah, telah dikupas pada QS. Al-Ahzab ayat 33.

Artinya: "Dan hendaklah kamu tetap di rumahmu dan janganlah kamu berhias dan bertingkah laku seperti orang-orang Jahiliyah yang dahulu dan dirikanlah shalat, tunaikanlah zakat dan taatilah Allah dan RasulNya. Sesungguhnya Allah bermaksud hendak menghilangkan dosa dari kamu, Hai ahlul bait dan membersihkan kamu sebersih-bersihnya".

Ayat ini seringkali digunakan dasar untuk menghalangi perempuan keluar rumah, untuk itu para pakar tafsir memberikan penafsiran sebagai berikut:

a. Al-Qurthubi berpendapat bahwa makna ayat ini perintah untuk menetap di rumah, walaupun redaksi ayat ini ditujukan kepada istri-istri Nabi, akan tetapi mencakup seluruh perempuan. Dengan alasan, agama dipenuhi oleh tuntunan agar perempuan tinggal di rumah, kecuali keadaan darurat.

b. Ibu Katsir berpendapat, ayat ini merupakan larangan bagi perempuan untuk keluar rumah jika tidak ada kebutuhan yang mendesak yang dibenarkan oleh agama.

c. Al-Maududi berpendapat dalam kitab Al-Hijab bahwa para ahli qiraah dari Madinah dan sebagian ulama Kuffah membaca kata "waqarna” pada ayat itu ditafsirkan "tinggallah di rumah kalian dan tetaplah berada di sana". Sedangkan ulama Basrah dan kuffah membacanya "waqirna” ditafsikan "tinggallah di rumah kalian dengan tenang dan hormat". Selanjutnya beliau menjelaskan bahwa " Tempat perempuan berada di rumah, mereka tidak dibebaskan dari pekerjaan luar rumah, kecuali agar mereka selalu berada di rumah dengan tenang dan hormat, sehingga mereka dapat melaksanakan kewajiban rumah tangga. Jikalau ada hajat keperluannya, maka boleh saja keluar rumah dengan syarat memperhatikan segi kesucian diri dan memelihara rasa malu. Dengan demikian, perempuan dibolehkan keluar rumah karena ada keperluan atau kebutuhan, dan yang dilarang dalam ayat ini adalah berhias dengan menampakkan perhiasan dan keindahan atau keangkuhan dan kegenitan berjalan.

${ }^{7}$ M.Quraish Shihab, 2006, Tafsir Al-Mishbab: Pesan, Kesan dan Keserasian Al-Qur'an, Volume 2, Jakarta: Lentera hati, hal. 416-419. Apabila diperhatikan asbabun-nuzul ayat ini tentang pertanyaan Ummu Salamah (Istri Rasulullah) kepada Rasulullah : Wahai Nabi, sesungguhnya kaum pria berjihat mengangkat senjata melawan musuh, sedangkan kaum perempuan tidak demikian. Kami juga selaku perempuan hanya mendapatkan setengah bagian dari laki-laki... Baca Shaleh, Dahlan, MD. Dahlan, t.t. Asbabun Nuzul : Latar Belakang Historis Turunnya Ayat-ayat Al-Qur'an, Cetakan ke-4, Bandung: CV.Diponogero, hal.129 meriwayatkan bahwa Ummu Salamah (istri N.Muhammad) bertanya kepada Nabi: "Kaum laki-laki berperang, sedang kaum perempuan tidak, dan kita hanya mendapat setengah bagian warisan laki-laki". Untuk memberikan jawaban istrinya, maka Allah menurunkah ayat ini sebagai teguran untuk tidak beriri hati pada ketetapan Allah (Diriwayatkan oleh at-Tirmidzi dan al-Hakim yang bersumber dari Ummu Salamah). Dalam riwayat lain dikatakan bahwa seorang perempuan mengadu kepada Nabi dengan berkata: Ya Nabiyullah ? laki-laki mendapat dua bagian kaum perempuan dalam waris, dan 2 orang saksi perempuan sama dengan seorang sakdi laki-laki. Apakah di dalam beramal pun demikian juga ?.(yaitu amal baik seorang perempuan mendapatkan pahala setengah dari jumlah pahala laki-laki), maka turunlah ayat ini sebagai penegasan bahwa laki-laki dan perempuan akan mendapat imbalan yang sama sesuai dengan amalnya (Diriwayatkan oleh Ibnu Abi Hatim yang bersumber dari Ibnu Abbas).

${ }^{8}$ Al-Qur'an dan Terjemahnya, hal. 672 
d. Tim penyusun tafsir yang diterbitkan oleh Kementerian Agama RI berpendapat bahwa ada peluang bagi perempuan untuk keluar rumah, persoalannya adalah batas-batas apa saja yang dibolehkan, apakah seperti bekerja di luar rumah ?.

e. $\quad$ Sayyid Quthb berpendapat dalam kitabnya: (1) Ma'rakat At-Taqalid, bahwa ayat ini bukan berarti perempuan tidak boleh keluar rumah = bekerja, karena Islam tidak melarang perempuan bekerja. Hanya saja Islam tidak senang (tidak mendorong) perempuan untuk bekerja, namun Islam membenarkan dan membolehkan perempuan bekerja karena darurat dan tidak menjadikan sebagai dasar pokok. (2) Kitab Syubuhat Haula Al-Islam bahwa perempuan pada awal zaman Islam pun bekerja, ketika kondisi menuntut mereka untuk bekerja. Masalahnya bukan terletak pada ada atau tidaknya hak perempuan untuk bekerja, namun Islam tidak mendorong perempuan untuk keluar rumah, kecuali untuk: pekerjaan-pekerjaan yang sangat perlu, pekerjaan yang dibutuhkan oleh masyarakat, atau kebutuhan yang diperlukan oleh perempuan tertentu. Seperti: kebutuhan untuk bekerja, karena tidak ada yang membiayai hidupnya atau yang menanggung hidupnya tidak mampu mencukupinya. (3) Kitab Fi Zhilal Al-Qur'an, bahwa arti kata "waqarna" pada ayat "waqarna fi buyutikunna" diartikan dengan "berat, mantap dan menetap". Dalam hal ini beliau mengisyaratkan bahwa rumah tangga merupakan tugas pokok yang harus dilakukan oleh perempuan, sedangkan aktifitas lainnya bukan tugas pokok perempuan. Dengan kata lain, beliau membolehkan perempuan meninggalkan rumah untuk memenuhi kebutuhan hidup, walaupun itu bukan tugas pokoknya.

f. Sa’id Hawa, ulama Mesir kontemporer memberikan contoh apa yang dimaksud dengan kebutuhan, seperti: mengunjungi orang tua, belajar atau menuntut ilmu yang sifatnya wajib dan bekerja untuk memenuhi kebutuhan hidup, karena tidak ada orang menanggungnya'.

Bertolak pada beberapa pendapat di atas, maka para ulama kontemporer berupaya menelaah keterlibatan perempuan pada pekerjaan di pada masa Nabi SAW., sahabat Nabi dan para tabiin, sehingga dapat ditemukan keragaman pekerjaan yang dilakukan oleh kaum perempuan pada saat itu. Sedangkan nama dan pekerjaan yang dilakukan oleh perempuan saat itu adalah:

a) Hak-hak perempuan dalam memimpin perang, aktivitas ini dilakukan oleh kaum perempuan pasca wafatnya khalifah Usman bin Affan. Seperti: Siti Aisyah (istri Rasullah) sebagai pimpinan perang yang terkenal dengan perang Jamal, Ummu Salamah ${ }^{10}$ (istri Rasulullah), Shafiyah, Laila Al-Ghaffariyah dan

${ }^{9}$ M.Quraisy Shihab , Ibid, Wawasan Al-Qur'an ..., hal. 303 - 305 Tokoh ulama yang memberikan kontribusi pemikiran dalam hal hak-hak perempuan di luar rumah pada tulisan ini adalah: Al-Qurthubi, sebagai seorang pakar tafsir, khususnya dalam bidang hukum. Ibnu Katsir seorang tokoh di bidang tafsir dan kitab tafsirnya terenal dengan nama Tafsir al-Qur'an al-'Azhim. Al-Maududi, seorang pemikir Muslim kontemporer dari Pakistan, sedangkan Muhammad Quthb salah seorang pemikir Ikhwan Al-Muslimun

${ }^{10}$ Abdurrahman Ra'fat Basya, Shuwarun Min Hayatis Shahabat, Darun Nafa'is - Bairut, t.h, alih bahasa Kepahlawanan Generasi Sahabat Rasulullah, 2003, Jakarta: Media Dakwah, hal. 56-66, Ummu Salamah mendapat julukan srikandi muslimah dengan nama aslinya Hindun, dia digelari atau dipanggil Ummu Salamah, karena anaknya bernama Salamah dan nama gelarnya yang lebih popular. Salamah merupakan anak Hindun dengan suaminya (sebelum menikah dengan Rasulullah) Abdullah bin 'Abdil Asad, pasangan ini termasuk kelompok 10 orang yang mula-mula masuk Islam, setelah tersiarnya kabar masuk Islam pasangan ini, maka mayarakat pengikutnya sangat marah dengan melakukan kekerasan dan memaksanya untuk murtad, tetapi siksaan yang diterimanya ternyata tidak membuat mereka murtad. Pasangan ini mendapat terror terus menerus, akhirnya Rasulullah mengizinkan dia bersama sahabat lainnya untuk hijrah ke Habasyah, Etiopia (Afrika). Mereka di Habasyah dilindungi oleh Raja Najasyi, meski demikian rasa rindu kota Mekkah selalu mengaduk-aduk hatinya untuk kembali ke tempat kelahirannya, kota suci, tempat turunnya wahyu, juga tempat bersemayan kekasih yang mereka cintai, baginda Rasulullah sebagai pembimbing dan Pembina umat yang beragama dengan agama yang benar. Disisi lain, para perantau mendengar kabar kalau kaum Muslimin di Mekkah bertambah banyak, diantaranya masuknya Islam Hamzah bin 'Abdul Muthalib (paman Nabi) dan Umar bin Khattab (tokoh Qureisy dan selanjutnya menjadi khulafaur rasyidin ke-2), akhirnya pasanga ini memutuskan untuk kembali ke Mekkah dan keduanya termasuk orang yang pertama kembali ke Mekkah. Ternyata suasana kota Mekkah tidak mendukung bagi kaum 
Jurnal Perempuan dan Anak, 1(1):

Ummu Sinam Al-Aslamiyah. Nama-nama tersebut merupakan para tokoh perempuan yang terlibat dalam mengatur strategi perang.

Muslimin, rintangan dan teror dari kaum musyrikinpun semakin menjadi, hingga Rasulullah memerintahkan kaum Muslim untuk hijrah ke Madinah, termasuk Ummu Salamah, suami dan anaknya memutuskan berhijrah ke Madinah. Ketika keluarga Abu Salamah (suami Hindun/Ummi Salamah) hampir sampai diperbatasan antara Mekkah dan Madinah, maka beberapa orang dari Bani Mahzum menghadang dengan mengatakan: wahai Abu Salamah (bapaknya Salamah = istri Hindun), engkau boleh meninggalkan negeri ini, tetapi istrimu jangan dibawa, karena dia dari suku kami (perlu kami sampaikan bahwa, ayah Hindun atau Ummu Salamah adalah pemimpin Banu Makhzum yang terpandang dan terkenal sebagai orang yang amat pemuruh, sehingga dijuluki "Zaadur Raakib"= penyantun musyafir, mengingat setiap musyafir yang datang ke rumahnya atau berjalan bersamanya dengan pasti diberi bekal). Selanjutnya, suami Ummu Salamah diserang hingga tidak berdaya. Ketika itu, orang-orang dari Bani Asad (kabilah dari suami Ummu Salamah) mengetahui peristiwa itu, maka mereka Bani Asad marah dengan mengatakan: silahkan ibunya (Ummu Salamah) engkau pisahkan dengan suaminya, tetapi anaknya jangan dibawa, karena anak kecil ini adalah anak cucu kami dan kami lebih berhak dari pada kalian semua. Saat itulah, keluarga ini berpisah, suaminya hijrah ke Madinah, Ummu Salamah dibawa pengawasan sukunya Bani Makhzum dan anaknya dibawa Bani Asad. Perpisahan ini kurang lebih selama 1 tahun, dan setiap hari yang dikerjakan oleh Ummu Salamah adalah pergi ke tanah lapang, menangis dan membayangkan suami dan anaknya. Hingga suatu saat, lewatlah anak pamannya dan iba melihat Ummu Salamah. Selanjutnya, anak pamannya ini menemui kaum Makhzum dan berkata: Sampai kapan kalian memperlakukan perempuan tersiksa seorang diri seperti ini, kalian pisahkan dengan anak dan suaminya, alangkah kejamnya kalian !. Sejak itu, kau Mahkzum berangsur-angsur lunak hatinya dan melepaskan Ummu Salamah untuk menemui suaminya. Setelah Ummu Salamah terbebaskan, maka ada baberapa orang yang membantunya untuk menemui Bani Asad, dengan tujuan untuk memintah Salamah (anaknya Ummi Salamah) disatukan dengan ibu-bapaknya. Usaha ini berhasil, saat itu juga ibu dan anak ini bersiap-siap menuju Madinah dengan mengendarai unta. Sampai di Tan'im, dia bertemu dengan Usman bin Thalkhah (ketikah itu masih musyrik) dengan bertanya: hendak kemana wahai Binti Zaadhur Raakib ? Ummu Salamah menjawab: saya hendak menemui suami saya di Madinah. Usman bertanya: dengan siapa kamu kesana, dia menjawab, dengan Allah dan anakku ini, Usman berkata: Demi Allah, saya tidak akan membiarkan engkau musafir sendirian. Selanjutnya, dipeganglah tali untanya Ummu Salamah hingga sampai di perkampungan Bani 'Amar bin Auf di Quba. Usman berkata: suamimu tinggal di kampong itu, pergilah ke sana dengan berkat Allah, dan Usman kembali ke Mekkah. Tidak lama mereka berkumpul dengan suaminya, maka Allah menguji imannya dengan adanya perang Badar. Suaminya ikut berperang, dengan pulang selamat. Tidak lama kejadian ini, terjadilah perang Uhud, suaminya pulang dengan kondisi luka parah dan Ummu Salamah yang merawatnya. Pada suatu hari, ketika Ummu Salamah sedang mengobati suaminya, suaminya berkata: wahai istriku: aku pernah mendengar Rasulullah bersabda: "Apabila seseorang ditimpah musibah, maka hendaklah dia membaca istirja' (Inna lillahi wa inna ilaihi raajiun) dan mendoakan : Ya Allah, aku berserah diri kepada Engkau terkait dengan musibah yang menimpah aku, karena itu gantillah aku den gan yang lebih baik, niscaya Allah memeperkenankan". Abu Salamah wafat pada saat subuh, dan saat itu Rasulullah sedangng menjenguknya, namun belum sampai di pintu rumahnya, Abu Salamah sudah wafat. Rasulullah menutupkan kedua kelopak matanya, dan beliau memandang ke langit seraya berdoa : "Ya Allah, ampunillah Abu Salamah, angkatlah derajatnya setaraf dengan orang-orang mutaqqin. Gantilah dia bagi keluarga yang ditinggalkannya. Ampunilah kami dan dia, wahai Allah Dzat semesta alam, lapangkanlah dan beri dia cahaya dalam kuburnya". Doa yang dibaca Rasulullah ini mengingatkan Ummu Salamah ketika mengobati suaminya dan suaminya membacakan hadits ini, doa ini hanya dibaca oleh Ummi Salamah pada bait pertama saja. Dengan peristiwa ini, kaum muslimin Muhajirin dan Anshar turut bersedih, mengingat Ummi Salamah tidak memiliki kelaurga di Madinah, hingga dia mendapat julukan "Ayyimul Arab" (janda Arab). Setelahmasa "iddahnya selesai, maka Abu Bakar dating untuk melamarnya, namun lamoran itu ditolak. Selanjutnya Umar melawar, itupun ditolak. Sesudah itu, baru Rasulullah melamarnya. Sebelum menerima lamaran Rasulullah, maka Ummu Salamah mengajukan 3 masalah yang harus dijawab oleh Nabi, yaitu: (1) Saya wanita sangat pencemburu, karena itu saya takut kalau Rasulullah menemukan sesuatu yang menjengkelkan dari diri saya, sehingga saya berdosa dan siksaan Allah menimpah saya. Rasulullah menjawab, insya Allah saya doakan, semoga dihilangkan Allah darimu. (2) Saya sudah tua, tidak pantas menikah lagi. Jawab Rasulullah, aku pernah menikahi perempuan yang lebih tua usianya dari akau. (3) Saya mempunyai anak, mana mungkin akan menikah lagi. Jawab Rasulullah, anakmu juga anak saya". Tidak lama kemudian, Rasulullah menikah dengan Ummu Salamah. Dia tidak hanya ibunya Salamah, tetapi ibunya orang-orang mukmin, hingga mendapat panggilan "Ummul Mukminin". 
b) Hak perempuan dalam merawat korban peperangan, juga mengatur dan menyiapkan logistik dapur umum ketika peperangan.

c) Keterlibatan perempuan dalam jihat, dan lain-lain. Semua itu terangkum dalam kitab shahih Imam Bukhari tentang kegiatan kaum perempuan.

d) Keterlibatan perempuan sebagai pimpinan perdagangan, sebut saja Khadijah (istri Rasulullah), Qilat Ummi Bani Anmar, Zainab binti Jahsy (pimpinan pengusaha kulit), Raithah, dan lain-lain ${ }^{11}$.

3. Hak-hak perempuan mencari ilmu, telah diungkap lewat QS. Ali Imran ayat 195 dan hadits Nabi sebagai berikut:

Artinya : "Maka Tuhan mereka memperkenankan permohonannya (dengan berfirman): "Sesungguhnya aku tidak menyia-nyiakan amal orang-orang yang beramal di antara kamu, baik laki-laki atau perempuan, (karena) sebagian kamu adalah turunan dari sebagian yang lain. Maka orang-orang yang berhijrah, yang diusir dari kampung halamannya, yang disakiti pada jalan-Ku, yang berperang dan yang dibunuh, pastilah akan Ku-hapuskan kesalahan-kesalahan mereka dan pastilah aku masukkan mereka ke dalam surga yang mengalir sungai-sungai di bawahnya, sebagai pahala di sisi Allah. dan Allah pada sisi-Nya pahala yang baik" ${ }^{12}$. Sabda Nabi "Thalabu al'ilmi farïdhatun 'ala kulli muslimin wa al-muslimat", artinya "Menuntut ilmu adalah kewajiban bagi setiap muslim dan muslimah”(HR. Al-Thabari melalui Ibnu Mas’ud).

Bertolak pada ayat dan hadits tersebut, maka hak laki-laki dan perempuan dalam mencari ilmu dan mengamalkannya adalah sama dihadapan Allah, mereka menyadari akan kewajibannya, sehingga memohon kepada Nabi untuk meluangkan waktu mengajarinya. Permohonan mereka untuk menuntut ilmu dikabulkan oleh Rasulullah, hingga Allah mengabadikan dalam Al-Qur'an S.Ali Imran ayat 195 dengan sebutan $u l u l$ albab $b^{13}$. Para ulul albab ini tidak hanya didominasi oleh kaum laki-laki, tetapi kaum perempuan juga ikut bergabung. Dengan kata lain, perempuan dapat berfikir seprti yang dilakukan oleh laki-laki, selanjutnya mempelajari dan mengamalkan apa yang mereka hayati setelah berzikir kepada Allah, serta mengetahui dari alam raya ini. Terkait dengan ilmu pengetahuan, Allah juga berfirman pada QS.Al-Alaq 15, QS.Az-Zumar 9, QS.Al-Mujadilah 11 dan hadits yang artinya: "Mencari ilmu itu adalah wajib bagi orang Muslimin dan Muslimat" . Substansi Ayat dan hadits ini dapat disimpulkan, bahwa seorang yang berilmu pengetahuan memiliki kedudukan tinggi sekalipun berasal dari golongan rendah, sebab Islam tidak memandang derajat dan keturunan, tetapi yang dipandang Islam adalah ilmunya, amal, taqwa, kejujuran dan kesuciannya. Oleh karena itu, para ulama, pelajar maupun sarjana merupakan kelompok orang-orang yang memiliki posisi cukup mulia.

Berbagai contoh ini menujukkan, bahwa perempuan mempunyai hak untuk bekerja selama ia membutuhkannya atau pekerjaan itu membutuhkan dia, juga selama norma-norma agama dan susila tetap terpelihara. Sedangkan bentuk dan ragam pekerjaan pada masa N.Muhammad dengan sekarang tentunya ada yang sama dan ada yang tidak. Oleh karena itu, sebagian Ulama' menyimpulkan bahwa Islam membenarkan kaum perempuan aktif dalam berbagai kegiatan atau bekerja dalam berbagai bidang, baik pada instansi pemerintah maupun swasta, di dalam rumah maupun di luar rumah dengan cara mandiri atau berkelompok. Selama pekerjaan tersebut dilakukan secara sopan, terhormat, dapat memelihara agamanya, dan dapat menghindari dampak negatif pekerjaan tersebut.

\footnotetext{
${ }^{11}$ M.Quraisy Shihab , Wawasan Al-Qur'an ..., hal. 306

${ }^{12}$ Al-Qur'an dan Terjemahannya, hal. 110

${ }^{13}$ Ulul albab adalah sebutan bagi orang mau berzikir dan memikirkan kejadian langit dan bumi. Orang yang mau menjadi ahli zikir dan pemikir dalam hal ini, dapat mengantarkan dirinya untuk mengatahui rahasia -rahasia alam semsta.

${ }^{14}$ Ibnu Majah, Al Hafiz Abu Abdillah Muhammad bin Yazid, Sunan Ibnu Majah, (t.k: t.p, tt), hal. 81, dalam Ridwan Nasir, 2010, Mencari Tipologi Format Pendidikan Ideal, Pondok Pesantren di Tengah Arus Perubahan, Cetakan II, Yogyakarta: Pustaka Pelajar, hal.60
} 


\section{Posisi Perempuan dalam hadits "Aljannatu tahta aqdamil umahat".}

Surga merupakan janji Allah untuk semua hambanya, termasuk hamba yang memperoleh sebutan ibu. Ibu.. ibu... ibu, engkaulah orang yang pantang menyerah tugas dalam memberikan pelayanan untuk memenuhi kebutuhan yang diperlukan anak-anakmu maupun suamimu. Meski tubuhmu lelah, tapi ... engkau tidak menunjukkan kecapekan dihadapan anak dan suamimu. Justru sebaliknya, yang engkau tunjukkan adalah keceriahanmu, kasih sayangmu dan tanggung jawabmu sebagai ibu. Engkau telah melakukan berbagai aktifitas di rumah, mulai bangun pagi sebelum subuh hingga menjelang tidur malam, belum lagi di tengah malam engkau terbangun untuk memberikan sesuatu dari permintaan anakmu. Pendek kata, tugas dan tanggungjawabmu mulai dari sector domestic hingga sector public tanpa mengenal lelah.

Bertolak pada berbagai tugas dan tanggungjawab tersebut, maka tidaklah berlebihan bila Rasulullah memberikan sebuah hadiah atau penghargaan lewat sabdanya "Aljannatu tahta aqdamil ummahat"= surga di bawah telapak kaki ibu. Dalam hal ini timbul pertanyaan, ibu yang mana bisa masuk surga ? Jawabannya: ternyata siapapun ibu bisa sebagai penghuni surga. Ibu-ibu bisa memilih mulai surga tingkatan dasar hingga tingkatan VIP, mengingat surga itu ada 7 tingkatan,sebagaimana neraka ada 7 tingkatan. Oleh karena itu, para ibu mulai sekarang dapat memilih dan memesan tingkatan surga yang diinginkan. Untuk memesan surga tentunya harus memiliki tiket sebagai alat atau sarana untuk masuk surga, dan pembayaran tiket dalam bentuk sebagai berikut :

1. Niat, bulatkan niat anda sebagai ibu, sebagaimana sabda Nabi:

$$
\text { إنما الأعمال بالنيات و إنما لكل امريء مانوى }
$$

"Innamal a'maalu binniyaati wainnamaa likulli-mrïn maa nawa”,Artinya "Sesungguhnya seluruh amal perbuatan itu tergantung pada niat, dan setiap orang hanya memperoleh apa yang dia niatkan" (Muttafaq 'alaih).

Niat adalah sesuatu yang direncanakan dengan sungguh-sungguh untuk diwujudkan dalam kenyataan (perbuatan) sebagai ibu dari anak-anaknya. Oleh karena itu, niat harus muncul dari hati yang bersih dan suci, semata-mata mengharap ridha Allah yang selanjutnya ditindaklanjuti dengan: (a) Mujahadah, yaitu berusaha dengan sungguh-sungguh untuk mewujudkan niat dalam bentuk amal (perbuatan) dan konsisten dengan sesuatu yang direncanakan. Maksudnya, perempuan yang sudah membulatkan niat untuk menjadi ibu, maka harus konsisten untuk merencanakan ke depan akan dikemanakan anggota keluarganya. Disamping itu, ibu bersama suami harus memainkan peran untuk melibatkan diri dalam mengurus dan membimbing anak-anak dan keluarganya. (b) Muhasabah, yaitu melakukan control dan evaluasi terhadap rencana yang telah dilakukan. Artinya, orang tua (suami-istri) harus melakukan control setiap saat terhadap tingkah laku maupun ucapan anggota keluarganya sedini mungkin, hingga tidak terjadi hal-hal yang tidak diinginkan. (c) Bersyukur kepada Allah, maksudnya suami-istri bersama anak-anaknya selalu memuji Allah atas segala kebaikan yang telah diberikan kepadanya. Syukurnya anggota keluarga atau seorang hamba kepada Tuhannya dapat berupa: hati atau mengakui nikmat dalam batin, lisan atau membicarakan nikmat yang diterima secara lahir, dan anggota badan dijadikan sebagai sarana untuk taat kepada Allah ${ }^{15}$. Hal ini dapat dicontohkan dengan kekayaan yang dimilikinya, maka wujud bersyukur kepada Allah atas kekayaan harta benda yang didapatnya adalah: pertama mengetahui dan mengakui bahwa semua kekayaan yang didapat adalah karunia dari Allah. Usaha yang mereka lakukan untuk mencari harta benda hanyalah ihtiar semata, ihtiar tanpa taufiq dan ridho-Nya tidak akan menghasilkan apa yang diinginkan. Oleh karena itu, seseorang harus bersyukur kepada Allah Yang Maha Pemurah dan Pemberi Rezeqi. Kedua mengungkapkan rasa syukurnya dalam bentuk puji-pujian atau kalimat thaiyyibah, seperti: al-Hamdulillah, subhanallah, Allahu Akbar dan lain-lain. Ketiga sebagai bukti rasa syukurnya itu dengan amal perbuatan yang nyata, dengan cara memanfaatkan harta kekayaannnya pada jalan yang diridhoi Allah, baik untuk keperluan diri dan keluarganya, umat atau perjuangan di jalan Allah (fi sabilillah) ${ }^{16}$. (d) Bertaubat, ${ }^{17}$ apabila

15 Yunahar Ilyas, 2001, Kuliah Akhlaq, Cetakan IV, Yogyakarta: Lembaga Pengkajian dan Pengamalan Islam (LPPI), hal. 50-51.

${ }^{16}$ Terkait dengan syukur, perhatikan apa yang dikatakan oleh Afif 'Abd al-Fattah Thabbarah, Ruh ad-Din, hal. 194: "Tidaklah bersyukur orang yang tidak mencintai Allah dan tidak mengakui bahwa nikmat yang didapatnya berasal 
seorang muslim (termasuk seorang ibu) melakukan kesalahan atau kemaksiatan (maksudnya, semua perbuatan yang melanggar ketentuan syari'at Islam, baik dalam bentuk meninggalkan kewajiban atau melanggar larangan, termasuk dosa kecil atau besar), maka harus segera kembali (bertaubat) kepad Allah. Sebagaimana firman Allah QS. An-Nur ayat 31.

Artinya : .. dan bertaubatlah kamu sekalian kepada Allah, Hai orang-orang yang beriman supaya kamu beruntung ${ }^{18}$. Juga QS. At-Tahrim ayat 8.

Artinya: "Hai orang-orang yang beriman, bertaubatlah kepada Allah dengan taubatan nasuhaa (taubat yang semurni-murninya). Mudah-mudahan Rabbmu akan menutupi kesalahan-kesalahanmu dan memasukkanmu ke dalam jannah yang mengalir di bawahnya sungai-sungai, pada hari ketika Allah tidak menghinakan Nabi dan orang-orang mukmin yang bersama dia; sedang cahaya mereka memancar di hadapan dan di sebelah kanan mereka, sambil mereka mengatakan: "Ya Rabb Kami, sempurnakanlah bagi Kami cahaya Kami dan ampunilah kami; Sesungguhnya Engkau Maha Kuasa atas segala sesuatu"19

dari Allah. Tidak bersyukur orang yang tidak memuji Allah dengan lisannya dan juga tidak bersukur orang yang mengucapkan kata-kata yang tidak ada gunanya. Tidak bersyukur orang yang diberi ilmu oleh Allah, tapi tidak diamalkan dan tidak diajarkannya. Tidak bersyukur orang yang diberi Allah kekayaan, tetapi tidak dimanfaatkannya untuk kebaikan". Dan Ahmad Faridh, 1990, Pembersih Jiwa, Bandung: Pustaka, hal. 146-148, tentang syukur yang dihubungkan 3 aspek (hati, lisan dan anggota tubuh), sebagaimana dialog antara seorang laki-laki (-) dengan Imam Abu Hazm (+) berikut ini : (-) Apa syukurnya kedua mata itu ?, (+) Apabila engkau melihat sesuatu yang baik, engkau menceritakannya. Sebaliknya bila mana engkau melihat keburukan, engkau menutupinya. (-) Bagaimana dengan syukurnya telinga ? (+) Jika engkau mendengar sesuatu yang baik, peliharalah. Sebaliknya, jika engkau mendengarkan sesuatu yang buruk, cegalah. (-) Bagaimana dengan syukurnya tangan ? (+) Jangan mengambil sesuatu yan g bukan hakmu dan janganlah engkau menolak hak Allah yang ada pada kedua tanganmu. () Bagaimana dengan syukurnya perut ? (+) Hendaknya bawanhya berisi makanan, sedangkan atasnya berisi ilmu. () Bagaimana dengan syukurnya kemaluan ? (+) Abu Hazm menjawab dengan membaca QS.Al-Mukminun ayat 1-7

Artinya : (1) Sesungguhnya beruntunglah orang-orang yang beriman, (2) (yaitu) orang-orang yang khusyu' dalam sembahyangnya, (3) Dan orang-orang yang menjauhkan diri dari (perbuatan dan perkataan) yang tiada berguna, (4) Dan orang-orang yang menunaikan zakat, (5) Dan orang-orang yang menjaga kemaluannya, (6) Kecuali terhadap isteri-isteri atau budak yang mereka miliki*); Maka Sesungguhnya mereka dalam hal ini tiada terceIa. (7) Barangsiapa mencari yang di balik itu**) Maka mereka Itulah orang-orang yang melampaui batas. Keterngan : *) Maksud: budak-budak belian yang didapat dalam peperangan dengan orang kafir, bukan budak belian yang didapat di luar peperangan. dalam peperangan dengan orang-orang kafir itu, wanita-wanita yang ditawan biasanya dibagibagikan kepada kaum muslimin yang ikut dalam peperangan itu, dan kebiasan ini bukanlah suatu yang diwajibkan. imam boleh melarang kebiasaan ini. Maksudnya: budak-budak yang dimiliki yang suaminya tidak ikut tertawan bersama-samanya. **)Maksudnya: zina, homoseksual, dan sebagainya. (-) Bagaimana dengan syukurnya kaki ? (+) Jika kamu mengetahui seorang shaleh yang meninggal dunia dan engkau bercita-cita dan berharap seperti dia, dimana dia melangkahkan kakinya untuk taat dan beramal shaleh semata, maka contohlah dia. Dan apabila engkau bisa melihat seoraang mati yang engkau membencinya, maka bencilah amalnya, maka engkau menjadi orang bersyukur.

${ }^{17}$ Yunahar Ilyas, Kuliah Akhlaq, hal. 57-58, taubat berakar dari kata taba artinya kembali. Orang yang bertaubat kepada Allah berarti kembali dari sifat-sifat tercela menuju sifat terpuji, kembali dari larangan Allah menuju perintah-Nya, kembali dari maksiat menuju taat, menuju dari segala yang dibenci Allah menuju yang diridhoi-Nya, kembali dari yang saling bertentangan menuju saling menyenangkan, kembali kepada Allah setelah meninggalkanNya dan kembali taat setelah menetang-Nya.

${ }^{18}$ Al-Qur'an dan Terjemahannya, hal. 548

${ }^{19}$ Al-Qur'an dan Terjemahannya, hal.951 
Dua ayat ini menunjukkan perintah kepada orang-orang beriman untuk segera bertaubah, dan sekaligus menjadi renungan kita bersama adalah mengapa Allah merintah segera bertaubah ? Karena sebagian orang telah merencanakan untuk bertaubah ketika sudah pensiun, atau sudah tua atau produktif kerja sudah mulai menurun. Dengan kata lain, masa muda untuk foya-foya menuruti hawa nafsu sudah merasa puas, disitulah taubah baru dilakukan. Padahal seseorang tidak mengetahui kapan usianya diambil oleh Allah, apakah hingga usia tua rentah atau usia produktif, atau usia muda, dan lain-lain. Mengingat kematian adalah hak mutlak dari Allah, dan tidak seorangpun yang mengetahui kapan datangnya.Oleh karena itu, sebagai ibu hendaknya menyadari hal ini, termasuk memberi pemahaman kepada semua anggota keluarganya. Bertaubah tidak usah ditundah-tundah, karena bisa jadi apa yang sudah kita lakukan terdapat kesalahan dan diri kita tidak mengetahuinya.

2. Ihlas ${ }^{20}$, kata ini mudah sekali untuk diucapkan, namun susah untuk diamalkan dengan kesungguhan. Mengingat, ihlas selalu berkaitan dengan perbuatan atau aktivitas yang dilakukan oleh seseorang, tanpa adanya pamrih dan hanya semata-mata mengharapkan ridho Allah SWT. Oleh karena itu, apa saja yang dilakukan oleh ibu ada nilainya ihlas, maka ada 3 hal yang perlu diperhatikan, yaitu : (a) Hendaknya diniatkan karena Allah, bukan berdasarkan motivasi yang lain. Mengingat faktor niat sangat menentukan diterima tidaknya amalan seseorang, maka landasan niatnya hendaknya kepada Allah sematamata, bukan lainnya. (b) Beramal dengan sebaik-baiknya, maksudnya niat yang iklas harus dibarengi dengan perbuatan yang sebaik-baiknya dengan etos kerja yang tinggi dan secara profesional. Oleh karena itu, aktivitas yang dilakukan tidak boleh sembarangan atau acak-acakan, meskipun jerih payahnya tidak dinilai dengan rupiah. Oleh karena itu, seorang ibu harus meluruskan cara pandang anggota keluarganya, bahwa aktivitas yang dilakukan tidak ada hubungannya dengan honor, sehingga aktivitas yang dikerjakan bisa menperoleh hasil yang maksimal. (c) Pemanfaatan hasil usaha dengan tepat, maksudnya pemanfaatan hasil yang diperoleh dapat dimanfaatkan untuk dirinya (contohnya mencari pekerjaan dengan memperoleh uang), orang lain yang dan masyarakat secara umum.

3. Penciptaan lingkungan yang Islami, bahwa Islam tidak sekedar agama yang melekat pada pribadi anggota keluarganya, tetapi lebih dari itu, bagaimana setiap anggota keluarga sebagai hamba Allah dapat meraih ridhonya melalui kerja atau amal shaleh dengan memurnikan sikap penyembahan hanya kepada Allah. Hal ini mengandung makna bahwa Islam adalah agama yang mengajarkan orientasi kerja (achievement orientation) sejak di dalam rumah, dimulai dari menyelesaikan tugas dan tanggung jawab masing-masing. Untuk itu orang tua (khususnya ibu) hendaknya mengajak dan meneladani kepada setiap anggota keluarga sebagai hamba Allah dapat meraih ridha-Nya melalui berbagai aktivitas atau melakukan amal shaleh dimulai dari hal-hal yang kecil. Seperti: (a) Keluar- masuk rumah dengan mengucapkan salam. (b) Membiasakan anak-anaknya minta ijin orang tua bila akan meninggalkan atau keluar rumah disertai berjabatan tangan dan ketika datang atau masuk rumah. (c) Mengajak dan membiasakan anak-anak dan anggota keluarganya untuk hidup sehat, dengan mengkonsumsi makanan dan minuman yang sudah disediakan ibu dengan mengawali dan menutup dengan berdoa. (d) Orang tua, khususnya ibu hendaknya mengajak dan memberi contoh kepada anak-anaknya atau anggota keluarga untuk shalat berjamaah, walaupun hanya sekali dalam sehari. (e) Biasakan dan berikan contoh anak-anak untuk mengaji atau membaca Al-Qur'an di rumah walaupun hanya sekali dalam sehari, karena itu ibu harus memilihkan waktu yang tepat untuk anak-anaknya agar tidak berbenturan dengan belajar pelajaran sekolah. (f) Tanamkan rasa ihlas dan bersyukur kepada Allah dalam melakukan berbagai aktivitas, baik di rumah, di sekolah dan di masyarakat. (g) Biasakan anak-anakmu untuk saling bantu-membantu dalam menyelesaikan aktivitas di

${ }^{20}$ Yunahar Ilyas, Kuliah Akhlaq, hal. 28-29, bahwa Ikhlas berasal dari kata khalasha artinya bersih, jernih, murnih dan tidak bercampur. Setelah dibentuk menjadi ikhlash (masdar dari fi'il muta'addi menjadi khallasha) berate membersihkan atau memurnikan. Sedangkan ikhlas menurut istilah adalah beramal yang semata-mata mengharap ridho dari Allah. 
rumah, tentunya disesuaikan dengan kapasitas kemampuan mereka. Seperti: mengambil piring, gelas, sendok, baskom, menyapu, ngepel,dan lain-lain.

4. Memahami tugas utama sebagai ibu (orang tua), seperti: (a) Memberi pandangan yang sehat akan makna hidup, karena hidup adalah pilihan, ada yang baik dan jelek, mana yang harus ditanamkan orang tua kepada anak-anak dan anggota keluarganya. (b) Tidak berlebihan dalam memberikan kasih sayang, hindari rasa kehawatiran yang berlebihan kalau anaknya akan terpengaruh oleh keadaan sekelilingnya yang penuh dengan: tipu daya, kemaksiatan, kedhaliman. (c) Bersikap wajarlah dalam memberikan fasilitas material dan hindari untuk menuruti keinginan anak, lebih-lebih dapat membahayakan dirinya. (d) Ingatkan dan dampingilah anak-anak ketika belajar, sehingga waktu di rumah tidak hanya digunakan untuk bermain. (e) Arahkan dan kembangkan bakat-minat mereka, sehingga skill yang dimiliki bisa tertuangkan dalam suatu kegiatan yang pasti dan positif. (f) Berikan reward anak-anak setelah menyelesaikan suatu aktivitas, meski keberhasilan yang dilakukan belum maksimal, juga memberikan punishment (hukuman atau teguran) ketika anak melakukan kesalahan, baik dalam bentuk kata-kata maupun pukulan yang tidak menyakitkan, tetapi membuat dia jerah. (g) Hindari dalam memberikan pujian atau materi yang berlebih-lebihan, karena bisa jadi membuat anak malas. (h) Biasakan anak-anak untuk mandiri dan bertanggung jawab terhadap aktivitas yang dilakukan, baik terkait dengan kegiatan sekolah (menyelesaikan PR) dan kegiatan rumah (meletakkan permainan, tas dan buku sekolah, seragam sekolah, permainan dengan anak tetangga, dan lainlain). (i) Ajaklah dialog anak-anak kita untuk menuangkan ide-ide bagusnya, sehingga orang tua atau ibu bisa mengarahkan jalan yang seharusnya dilalui, dan lain-lain.

5. Mendoakan semuan anggota keluarganya, mengingat doa ibu ibarat sabda Tuhan pada tataran manusia, khususnya antara anak dengan ibu dan antara istri dengan suami. Oleh karena itu ketika anakanak minta izin untuk berangkat sekolah atau suami berangkat kerja, maka seharusnya minta izin kepada ibu dengan berjabat tangan, seraya mendoakan mereka dengan membaca "Barakallah = semoga Allah memberkahimu”. Selanjut ibu menitipkan kepada Allah ketika anak-anak dan suamimu keluar rumah, agar hati dan pikirannya diluruskan pada tujuan sucinya, yaitu menuntut ilmu dan bekerja mencari nafkah untuk menghidupi anak dan istrinya.

\section{Kesimpulan.}

Bertolak pada uraian di atas dapat disimpulkan, bahwa surga itu ada dibawa kaki ibu manakala ia mampu melakukan :

1. Niat, semata mencari ridho Allah dan ditindaklajuti dengan melakukan mujahadah, muhasabah, bersyukur kepada Allah dan bertaubat.

2. Ikhlas dalam melakakukan berbagai aktivitas, karena itu hendaknya diniatkan hanya kepada Allah, dan ditindaklanjuti dengan amalan atau perbuatan yang sebaik-baiknya, sehingga ada manfaat dari hasil usahanya.

3. Penciptaan lingkungan yang Islami, dimulai dari hal-hal yang kecil, namun sangat mendasar, seperti: mengucapkan salam, membiasakan pamit pada orang tua, membiasakan hidup sehat, dengan mengkonsumsi makanan dan minuman, mengajak dan memberi contoh untuk shalat berjamaah dan dilanjutkan mengaji, menanamkan rasa ihlas dan bersyukur kepada Allah, dan membiasakan saling bantumembantu dalam menyelesaikan aktivitas.

4. Memahami tugas utama sebagai ibu, seperti: member pemahaman akan makna hidup, tidak berlebihan dalam memberikan kasih sayang, bersikap wajar dalam memberikan fasilitas, mendamping ketika belajar, mengembangkan bakat-minatnya, memberikan reward maupun punishment dalam menyelesaikan aktivitas, hindari memberikan pujian yang berlebih-lebihan, membiasakan untuk mandiri dan bertanggung jawab, dan komunikasi dua arah selalu dilakukan.

5. Mendoakan semua anggota keluarganya selalu dilakukan, baik dalam keadaan lapang maupun dalam keadaan kalut.. 


\section{Daftar pustaka}

Hal. 1 - 13

Al-Qur'an dan Terjemahnya, 1427 H, Mujamma' Al Malik Fahd Li Thiba'at Al Mush-haf Asy-Syarif Madinah Al Munawwarah Kerajaan Arab Saudi

Jamal, Khalid, 2008, Inner Beauty: Tips Cantik Dunia Akhirat, Jakarta: Embun Publishing

Shihab, M.Quraish, 2003, Wawasan Al-Qur'an: Tafsir Maudhu'I atas Perbagai persoalan Umat, Cetakan $X I V$, Bandung: PT Mizan Pustaka.

Shihab, M. Quraish Shihab, 2006, Tafsir Al-Mishbab: Pesan, Kesan dan Keserasian Al-Qur'an, Volume 2, Jakarta: Lentera hati.

Shaleh, Dahlan, MD. Dahlan, t.t. Asbabun Nuzul : Latar Belakang Historis Turunnya Ayat-ayat Al-Qur'an, Cetakan ke-4, Bandung: CV.Diponogero

Abdurrahman Ra'fat Basya, Shuwarun Min Hayatis Shahabat, Darun Nafa'is - Bairut, alih bahasa Kepahlawanan Generasi Sahabat Rasulullah, 2003, Jakarta: Media Dakwah

Ahmad Faridh, 1990, Pembersih Jiwa, Bandung: Pustaka,

Yunahar Ilyas, 2001, Kuliah Akhlaq, Cetakan IV, Yogyakarta: Lembaga Pengkajian dan Pengamalan Islam (LPPI) 